\title{
Effect of New Herbicides on Yield Attributes and Yields of Soybean
}

\author{
Pundas, G.K. Shrivastava, Chandu Lal Thakur* and Sonendra Jangde \\ Department of Agronomy, College of Agriculture, Indira Gandhi Krishi Vishwavidyalaya, \\ Raipur, (CG)-492012, India \\ *Corresponding author
}

\section{A B S T R A C T}

\section{Keywords}

New herbicide, Yield attributes, Soybean

Article Info

Accepted:

15 January 2018

Available Online:

10 February 2018
A field experiment was conducted at Instructional-cum-Research Farm, Indira Gandhi Krishi Vishwavidiyalaya, Raipur (C.G.) to evaluate the effect of new herbicides on yield attributes and yields of soybean during kharif 2016. The experiment was laid out in randomized block design with three replications. Among the different weed management practices, treatment $\mathrm{T}_{9^{-}}$hand weeding twice at 20 and 40 DAS recorded significantly higher number of pods plant ${ }^{-1}$, number of seeds pod $^{-1}$, seed and stover yield as compared to others but, it was at par to $\mathrm{T}_{3}$ - Fomesafen $17.5 \% \mathrm{w} / \mathrm{w} \mathrm{ME}+$ Clodinafop 12.5\% w/w ME @ $1250 \mathrm{~g}$ a.i. ha ${ }^{-1}$ as PoE and $\mathrm{T}_{2}-$ Fomesafen $17.5 \%$ w/w ME + Clodinafop 12.5\% w/w ME @ $1000 \mathrm{~g}$ a.i. $\mathrm{ha}^{-1}$ as PoE.

\section{Introduction}

Soybean [Glycine max (L.) Merrill] is one of the most important oilseed crop in the world and it is also wonder crop of the $20^{\text {th }}$ century. It is a cheapest source of vegetable oil and protein. It contains about 40 percent protein, well balanced in essential amino acids, 18-20 per cent oil rich with poly unsaturated fatty acids specially Omega 6 and Omega 3 fatty acids, 6-7 percent total mineral, 5-6 percent crude fiber and 17-19 percent carbohydrates. Soybean builds up the soil fertility by fixing atmospheric nitrogen through the root nodules, and also through leaf fall on the ground on maturity. It is able to leave residual nitrogen effect for succeeding crop equivalent to 35-40 $\mathrm{kg} \mathrm{N} \mathrm{ha}{ }^{-1}$. Soybean is mainly grown during kharif season in sandy loam to clay loam soils in Chhattisgarh. In these soils, by virtue of their water holding capacity, do not turn up in working condition, hindering timely weeding and interculture operation. Weed flush come at same time in almost all the kharif crops, which also restrict the availability of manpower for weeding operation in this crop.

The untimely and poor weed management adversely affects proper growth and yield of soybean. The critical period of crop weed competition in soybean is reported to be first 45 DAS (Panneerselvam and Lourduraj, 
2000). The yield loss due to weed infestation in soybean was to the tune of 20-77 per cent (Kurchania et al., 2001).

Wide spectrum new herbicides are required to control the majority the weed flora in soybean crop. Mostly the farmers are using pre-plant incorporated and pre-emergence herbicides for weed control in soybean, but their efficacy are reduced by various climatic and edaphic factors. Hand weeding is a traditional and effective method of weed control, but untimely and continuous rains as well as unavailability of labour at peak time are main limitations of manual weeding. The only alternative that needs to be explored is the use of post-emergence herbicides. The screening of such herbicides in soybean reveals their efficiency against either monocotyledonous or dicotyledonous weeds. Hence, their mixtures may broaden the window of weed management by broad-spectrum weed control (Bineet et al., 2001).

Unavailability of adequate labourers during peak weeding time and difficulty in use of mechanical means for weed management due to rains also add more problems. Hence, there is need to evaluate the efficacy of grass killers in different crop ecosystems. It is also necessary to work out the efficacy of newer herbicides when ever developed in terms of their effect on yield attributes and yield under varied agro-climatic situations before recommending them to the farming community.

\section{Materials and Methods}

A field experiment on effect of new herbicides on yield attributes and yields of soybean was conducted at Instructional cum Research Farm, Indira Gandhi Krishi Vishwavidyalaya, Raipur (C.G.) during kharif 2016. The experiment was laid out in Randomized Block Design (RBD) with three replications and ten weed management treatments which included viz. $\mathrm{T}_{1}-$ Fomesafen $17.5 \%$ w/w $\mathrm{ME}+$ Clodinafop 12.5\% w/w ME @ 750 g a.i. ha ${ }^{-1}$ as PoE, $\mathrm{T}_{2}-$ Fomesafen $17.5 \%$ w/w $\mathrm{ME}+$ Clodinafop 12.5\% w/w ME @ 1000 g a.i. ha ${ }^{-1}$ as PoE, $\mathrm{T}_{3}-$ Fomesafen $17.5 \%$ w/w $\mathrm{ME}+$ Clodinafop 12.5\% w/w ME @ 1250 g a.i. ha ${ }^{-1}$ as PoE, $\mathrm{T}_{4^{-}}$Clodinafop 12.5\% w/w M @ 1000 g a.i. ha $^{-1}$ as PoE, $\mathrm{T}_{5^{-}}$Fomesafen $17.5 \% \mathrm{w} / \mathrm{w}$ ME @ 1000 g a.i. ha ${ }^{-1}$ as PoE, T $6^{-}$Fomesafen $11.1 \%$ w/w + fluzifop-p-butyl 11.1\% w/w SL @ $1000 \mathrm{~g}$ a.i. ha ${ }^{-1}$ as PoE, T $7^{-}$Imazythapyr @ $300 \mathrm{~g}$ a.i. ha $^{-1}$ as PoE, T $8^{-}$Quizalofop ethyl + chlorimuron ethyl @ 400+16 g a.i. ha ${ }^{-1}$ as PoE, T $9^{-}$Hand weeding twice at 20 and 40 DAS and $\mathrm{T}_{10^{-}}$Weedy check. All the treatments were applied at 20 DAS (Day after sowing) as a tank mix at time of spraying. Soybean variety JS-335 was sown with spacing of $30 \times 5 \mathrm{~cm}$ and seed rate of $75 \mathrm{~kg}$ $\mathrm{ha}^{-1}$ was used.

The observation was taken by using five plant samples as per standard procedures and grain and straw yield were taken using net plot technique after removing two rows of border. Harvest index was calculated by the following formula:

Grain yield
Harvest index $(\%)=$-------------- x 100
Biological yield (grain + straw)

\section{Results and Discussion}

\section{Yield attributes}

The finding revealed that significant higher number of pods plant ${ }^{-1}$ was recorded in $\mathrm{T}_{9^{-}}$ hand weeding twice at 20 and 40 DAS followed by $\mathrm{T}_{3}$ - Fomesafen $17.5 \% \mathrm{w} / \mathrm{w} \mathrm{ME}+$ Clodinafop 12.5\% w/w ME @ 1250 g a.i. ha ${ }^{-1}$ as $\mathrm{PoE}$ and $\mathrm{T}_{2}-$ Fomesafen $17.5 \%$ w/w $\mathrm{ME}+$ Clodinafop 12.5\% w/w ME @ 1000 g a.i. ha ${ }^{-1}$ as PoE. The minimum number of pods plant ${ }^{-1}$ was recorded in $\mathrm{T}_{10^{-}}$weedy check (Table 1). 
Table.1 Effect of new herbicides on yield attributes, yield and harvest index of soybean

\begin{tabular}{|c|c|c|c|c|c|c|c|}
\hline Treatment & $\begin{array}{c}\text { Dose } \\
\left(\text { a.i. ha }{ }^{-1}\right) \\
\text { ml /g }\end{array}$ & $\begin{array}{c}\text { Pods } \\
\text { plant }^{-1} \\
(\text { No. })\end{array}$ & $\begin{array}{l}\text { Seeds } \\
\text { pod }^{-1} \\
(\text { No. })\end{array}$ & $\begin{array}{c}\text { 100-Seed } \\
\text { weight } \\
\text { (g) }\end{array}$ & $\begin{array}{c}\text { Seed } \\
\text { yield } \\
\left(\mathrm{kg} \mathrm{ha}^{-1}\right)\end{array}$ & $\begin{array}{c}\text { Stover } \\
\text { yield } \\
\left(\mathrm{kg} \mathrm{ha}^{-1}\right)\end{array}$ & $\begin{array}{c}\text { Harvest } \\
\text { Index } \\
(\%)\end{array}$ \\
\hline $\begin{array}{l}\mathrm{T}_{1} \text { - Fomesafen } 17.5 \% \mathrm{w} / \mathrm{w} \mathrm{ME}+ \\
\text { Clodinafop } 12.5 \% \mathrm{w} / \mathrm{w} \mathrm{ME}\end{array}$ & 750 & 81.12 & 2.63 & 8.43 & 1958 & 2799 & 41 \\
\hline $\begin{array}{l}\mathrm{T}_{2-} \text { Fomesafen } 17.5 \% \text { w/w ME + } \\
\text { Clodinafop } 12.5 \% \text { w/w ME }\end{array}$ & 1000 & 83.50 & 2.77 & 8.39 & 2075 & 3106 & 40 \\
\hline $\begin{array}{l}\mathrm{T}_{3^{-}} \text {Fomesafen } 17.5 \% \text { w/w ME + } \\
\text { Clodinafop } 12.5 \% \text { w/w ME }\end{array}$ & 1250 & 85.54 & 2.83 & 8.45 & 2075 & 3348 & 38 \\
\hline $\mathrm{T}_{4^{-}}$Clodinafop $12.5 \% \mathrm{w} / \mathrm{w} \mathrm{ME}$ & 1000 & 77.07 & 2.53 & 8.57 & 1958 & 2941 & 40 \\
\hline $\mathrm{T}_{5^{-}}$Fomesafen $17.5 \%$ w/w ME & 1000 & 65.01 & 2.57 & 8.57 & 1490 & 3008 & 33 \\
\hline $\begin{array}{l}\mathrm{T}_{6} \text { - Fomesafen } 11.1 \% \mathrm{w} / \mathrm{w}+ \\
\text { fluazifop- p-butyl } 11.1 \% \mathrm{w} / \mathrm{w} \mathrm{SL}\end{array}$ & 1000 & 67.62 & 2.47 & 8.33 & 1607 & 2555 & 38 \\
\hline $\mathrm{T}_{7^{-}}$Imazethapyr & 300 & 66.10 & 2.53 & 8.55 & 1725 & 2776 & 38 \\
\hline $\begin{array}{l}\text { T }_{8-} \text { Quizalofop-ethyl + } \\
\text { chlorimuron -ethyl } \\
\end{array}$ & $400+16$ & 74.93 & 2.50 & 8.56 & 1965 & 2919 & 40 \\
\hline T $_{9-}$ Hand weeding & $\begin{array}{l}20-40 \\
\text { DAS }\end{array}$ & 87.03 & 3.07 & 8.13 & 2192 & 3439 & 39 \\
\hline $\mathrm{T}_{10^{-}}$Weedy check & - & 54.08 & 2.57 & 8.14 & 993 & 1854 & 35 \\
\hline SE $\mathbf{m} \pm$ & & 2.18 & 0.06 & 0.21 & 123 & 127 & 0.23 \\
\hline $\mathrm{CD}(\mathrm{P}=0.05)$ & & 6.47 & 0.19 & NS & 368 & 377 & NS \\
\hline
\end{tabular}


This result may be due to the less competition at critical periods of crop growth and better suppression of weeds, which allowed the crop to grow their potential by absorbing sufficient nutrients, light, moisture and space which facilitate more translocation of photosynthates towards the reproductive parts as well as presence of favourable agro-climatic conditions due to removal of weeds, led to more number of pods plant ${ }^{-1}$. Similar results have been reported by Kumar et al., (2001), Vyas and Jain (2003) and Kothawade et al., (2006).

The significantly higher number of seeds $\operatorname{pod}^{-1}$ was noted in treatment $\mathrm{T}_{9^{-}}$hand weeding twice at 20 and 40 DAS which was followed by $\mathrm{T}_{3}-$ Fomesafen $17.5 \%$ w/w ME + Clodinafop $12.5 \%$ w/w ME@1250 g a.i. ha ${ }^{-1}$ as PoE and $\mathrm{T}_{2^{-}}$ Fomesafen 17.5\% w/w ME + Clodinafop 12.5\% w/w ME@ 1000 g a.i. ha ${ }^{-1}$ as PoE. However, the minimum number of seeds pod ${ }^{-1}$ was recorded in $\mathrm{T}_{10^{-}}$weedy check.

100 seed weight of soybean seeds was not influenced due to different new herbicides.

The findings are supported by the observations of Amaregouda et al., (2013) who stated that the weight of 100 seed always shows the least variation under any cultural season and practices, compared to other components. 100 seed weight is a varietal character because the grain size is rigidly controlled by the size of the hull (Billore et al., 1999).

Kamalabai and Nanjappa (2003) mentioned that weed competition did not affect 100 seed weight of the soybean. This finding coincides with Kothawade et al., (2006) who also noted non-significant effects of weed competition on 100 seed weight.

The present findings are in conformity with the results of Singh et al., (2013) who reported that 100 seed weight is a genetic character widely used in yield estimation and varietal selection in soybean and environmental factors have minimum influence on it.

\section{Yield}

Treatment $\mathrm{T}_{9^{-}}$hand weeding twice at 20 and 40 DAS produced significantly higher seed yield followed by $\mathrm{T}_{2^{-}}$Fomesafen $17.5 \% \mathrm{w} / \mathrm{w} \mathrm{ME}+$ Clodinafop 12.5\% w/w ME @ 1000 g a.i. ha ${ }^{-1}$ as PoE and $\mathrm{T}_{3^{-}}$Fomesafen $17.5 \% \mathrm{w} / \mathrm{w} \mathrm{ME}+$ Clodinafop 12.5\% w/w ME @ 1250 g a.i. ha ${ }^{-1}$ as PoE. The lowest seed yield was recorded in $\mathrm{T}_{10^{-}}$weedy check. Similar findings were also reported by Tiwari et al., (2006), Karande et al., (2008) and Yadav et al., (2009). Higher seed yield under above treatments was due to the weed managed at critical period and early crop growth, higher dry matter production, high growth in terms of LAI, which resulted in higher production of photosynthesis, which acts as a source and greater translocation of food materials to the reproductive parts resulted in superiority of yield attributing characters and ultimately high yield. Lower weed population and higher weed control efficiency also resulted in higher grain yield. Contrarily, the poor growth of plants as well as development of yield attributing characters in weedy check might be due to less moisture, nutrient, space and light availability at the time of flowering and pod development adversely influenced the seed yield. The lower seed yield under weedy check may be due to the high weed interference.

With different new herbicides application, there was significant result was recorded for stover yield. The significantly higher stover yield was recorded in $\mathrm{T}_{9^{-}}$hand weeding twice at 20 and 40 DAS followed by $\mathrm{T}_{3}$-Fomesafen $17.5 \% \mathrm{w} / \mathrm{w}$ ME + Clodinafop 12.5\% w/w ME @ $1250 \mathrm{~g}$ a.i. $\mathrm{ha}^{-1}$ as PoE, and $\mathrm{T}_{2}-$ Fomesafen $17.5 \%$ w/w ME +Clodinafop 12.5\% w/w ME @ 1000 g a.i. ha ${ }^{-1}$ as PoE. The lowest stover yield was recorded in $\mathrm{T}_{10^{-}}$weedy check (Table 1 ). The higher stover yield in above treatments might be due to lesser weeds during early crop growth period and give higher yield attributes and pod yield which leads to higher stover yield. While, in weedy check reverse trend was observed and therefore, the lowest stover yield was noted under this treatment. Similar findings were reported by Dhane et al., (2009). Non-significant variation 
was observed in harvest index due to application of different new herbicides.

\section{References}

Amaregouda, A., Jadhav, J., Chetti, M.B. and Nawalagatti. 2013. Effect of weedicides on physiological parameters, growth, yield and yield components of soybean (Glycine max. L) and weed growth. Journal of Agriculture and Allied Sciences, 2(4): 12-15.

Billore, S.D., Joshi, O.P. and Ramesh, A. 1999. Herbicidal effect on nodulation, yield and weed control in soybean (Glycine max). Indian Journal of Agricultural Sciences, 69(5): 329-331.

Bineet, M., Andani, G. and Mohammed, T.A. 2001. Herbicide mixture in agriculture: A Review (In) Proceeding of Biennial Conference, Indian Society of Weed Scienc, pp. 236, held at Bangalore.

Dhane, J.B., Jawale, S.M., Shaikh, A.A., Dalavi, N.D. and Dalavi, P.N. 2009. Effect of integrated weed management on yield and economics of soybean (Glycine max L.Merrill). Journal of Maharashtra Agricultural University, 34(2): 141-143.

Kamalabai, S. and Nanjappa, H. V. 2003. Effect of herbicide on weed count and weight, yield and nodulation in soybean. Karnataka Journal of Agriltural. Science, 16: 208-12.

Karande, D.R., Kadam, G.L., Talnikar, A.S. and Jogdand, P. B. 2008. Integrated weed management in soybean (Glycine max). International Journal of Agricultural Science, 4(1): 107-113.

Kothawade, T.K., Sinare, B.T., Shete, B.T. and Londhe, T.B. 2006. Effect of different herbicides on growth and yield of soybean. Annals of Plant Physiology, 20(1): 59-61.

Kumar, P., Baghel, R.S. and Singh, S.P. 2001. Weed management in soybean (Glycine $\max$ (L.) Merrill). Progressive Agriculture, 1(1): 38-41.

Kurchania, S.P., Rathi, G.S., Bhalla, C.S. and Mathew, R. 2001. Bio efficiency of postemergence herbicides for weed control in soybean (Glycine max (L) Merrill). Indian Journal of Weed Science, 33(1\&2): 3437.

Panneerselvam, S. and Lourduraj, A.C. 2000. Weed sapectrum and effect of crop weed competition in soybean [Glycine max (L.) merrill]- A Review. Agriculture Review, 21(2): 121-124.

Singh, M., Kewat M.L., Dixit, A., Kumar, K. and Pal, V. 2013. Effect of post emergence herbicides on growth and yield of soybean (Glycine Max L.) Indian Journal of Weed Science, 45(3): 219-222.

Tiwari, T.K., Pawar, V.S. and Mahatale, P.V. 2006. Effect of soil solarization and herbicides on weed control in soybean. Annals of Plant Physiology, 20(1): 56-58.

Vyas, M.D. and Jain, A.K. 2003. Effect of pre and post-emergence herbicides on weed control and productivity of soybean. Indian Journal of Agronomy, 48(4): 309311.

Yadav, V.K., Sankpal, V.Y., Shaikh, A.A. and Bachkar, S.R. 2009. Effect of integrated weed management on yield and economics of soybean (Glycine max L. Merrill). Journal of Maharashtra Agricultural Universities, 34(1): 25- 27.

\section{How to cite this article:}

Pundas, G.K. Shrivastava, Chandu Lal Thakur and Sonendra Jangde. 2018. Effect of New Herbicides on Yield Attributes and Yields of Soybean. Int.J.Curr.Microbiol.App.Sci. 7(02): 15721576. doi: https://doi.org/10.20546/ijcmas.2018.702.189 